\title{
The Ukrainian Education in Galicia (1919-1939): A Search for an Ideal
}

Marija Czepil / e-mail: chepilmaria@gmail.com

Department of General Pedagogy and Preschool Education, Faculty of Psychology, Pedagogy \& Social Work, Drohobych Ivan Franko State Pedagogical University, Ukraine; Institute of Pedagogy, Maria Curie-Skłodowska University in Lublin, Poland.

Oresta Karpenko / e-mail: orestakarpenko@gmail.com

Department of General Pedagogy and Preschool Education, Faculty of Psychology, Pedagogy \& Social Work, Drohobych Ivan Franko State Pedagogical University, Ukraine.

Czepil, M. - Karpenko,O. (2020). The Ukrainian Education in Galicia (1919-1939): A Search for an Ideal. Czech-Polish Historical and Pedagogical Journal, 12/2, 112-121. https://doi.org/10.5817/cphpj-2020-025

The theoretical principles of the national education of children and students in the Ukrainian pedagogy of Galicia during 1918-1939 are scrutinized in the article. The approaches of the Ukrainian educators to the educational ideal, the purpose, content and tasks of the national education have been systematized. The focus on the national values (the national idea, the national unity, the national self-esteem, the national awareness), which are not innate but are formed in the process of the personal development and gaining the social experience on a qualitatively new content of education, in which the national and universal values are closely intertwined. The basis of education is the Ukrainian national idea as a desire for state independence.

Key words: the Ukrainian pedagogy; the Ukrainian education; the national values; the Ukrainian national idea; the educational ideal; Galicia

The First World War fundamentally changed the national and political situation of the Ukrainians. The schooling in Poland, and thus in Galicia, in the post-war years of the twentieth century developed against the background of the changing European political map. This process brought to the fore the national values (self-reliance, self-affirmation), which became possible only through the education of the people on the basis of the idea of nation building. The struggle for the Ukrainian statehood shifted from the theoretical to the concrete political plane. The Ukrainians of Galicia and the Dnieper Ukraine declared their loyalty to 
the states under whose domination they were. The schooling policy during this period "merges entirely with the public policy, and the problem of school increases their significance as a state problem: to be or not to be."1

The development of the theory of the Ukrainian education was facilitated by the scientific discussions that took place on the pages of Ukrainian-language pedagogical journals, which in the 1920-1930s were the main source of information about the research of the educators in Galicia. Teachers focused their efforts on developing the theoretical foundations of education, which included preparing young people to create their own independent state. This was due to the fact that the main purpose of the learning process was education, and teaching was considered as a means of education. Ivan Yushchyshyn (1883-1960) noted that in the teaching and education there was a great scientific movement, the search for new truths and ideals of education and education. ${ }^{2}$ It should be noted that the very name of one of the most influential magazines of the time changed: from 1927 to 1930 it was called "The Way of Education and Teaching" and since 1930 - the "Way of Teaching and Education".

The idea of the national education had to be solved through the prism of those tasks and aspirations that would meet the centuries-old hopes of the Ukrainian people to restore and build their own, independent and unified state. The Ukrainian statehood was the highest imperative in the national education, the most important thing was to preserve the national identity as much as possible, and a completed national identity could contribute to the human culture. ${ }^{3}$ The Ukrainian youth had to be educated based on the best national traditions, have an active position, be aware of themselves as "living and conscious members of a living, conscious and united organism." The common history, the heroic past, prominent people, as Stepan Siropolko noted (1872-1959), were the main capital on which the national idea was based. ${ }^{5}$ However, in Yakym Yarema's opinion (1884-1963), it would be a mistake to think that the education of children and young people only in their native culture would lead the nation to the desired power. ${ }^{6}$

1 Yarema, Y. (1934). Nova faza $v$ rozvytku yevropeyskoyi shkoly [A new phase in the development of a European school]. Ukrayinska shkola - [Ukrainian School], 19. Lviv, p. 5-6.

2 Yushchyshyn, I. (1930). Kolektyvizm chy indyvidualizm: Zauvahy do hromadivskykh instynktiv nashoho narodu [Collectivism or individualism: Observations on the public instincts of our people]. Shlyakh navchannya i vykhovannya - [The Path of Education and Upbringing], 5. Lviv, p. 130.

3 Halushchynskyi, M. (1920). Narodna osvita i vykhovannia: statti i zamitky [Public education and upbringing: articles and notes]. Lviv, p. 3.

${ }^{4}$ Franko, I. (1986). Halytske krayeznavstvo [Galician country lore]. In I. Franko, [Collected works: in 50 vols]. Kyiv: Naukova dumka. Vol. 46. p. 116.

5 Dilo (1924), February 6.

6 Yarema, Y. (1934). Nova faza v rozvytku yevropeyskoyi shkoly [A new phase in the development of a European school]. Ukrayinska shkola - [Ukrainian School], 19. Lviv, p. 11. 
Meditating on the educational ideal, Mykhaylo Haluschynskyi (1878-1931) drew a parallel between the purpose of education in different countries (the Soviet Union, Italy, Czechoslovakia, Poland). According to him, only in Czechoslovakia did the state take into account the needs of the national minorities. According to the scholar, the Polish school tried to educate every representative of the national minorities as a Polish patriot. As for the Ukrainian educational ideal, "we have already created such an ideal for ourselves. Especially the last five decades have been the development of a conscious national educational ideal that brought us to our state-building uprising of 1918. Especially we in Galicia, when our people were divided between the Austrian Empire and the Hungarian Kingdom, were that force to which the eyes of all Ukrainians, wherever they were, were looking. This role of the leading element is destined to us, especially since our people now inhabit several states in different conditions. We are aware of the great responsibility that we bear, and a clear desire to hold the Ukrainian national flag as high and proud as possible."7

Having analysed the views of Jean-Jacques Rousseau (1712-1778), Friedrich Wilhelm Nietzsche (1844-1900), Johann Friedrich Herbart (1746-1841) and other educators and philosophers, Ivan Yushchyshyn substantiated the ideal of the social education, taking into account socio-political conditions: "the educational ideal, in his opinion, must grow out of the historical conditions, social and spiritual needs of the era." 8 It must be in harmony with what the citizenry is heading to this day, what it needs and what it believes in.

The views of the Ukrainian educators of Galicia were close to those of the German scholar Georg Michael Kerschensteiner (1854-1932) on state-civic education, which they considered most appropriate for the revival of the nation. ${ }^{9}$ He regarded the civic consciousness as an integral quality that combines conscience, freedom, conviction, active life position, sense of duty and responsibility, love for one's people, motherland, and native language. He filled it with pedagogical content, universal, humanistic educational value. The school, according to Georg Kerschensteiner, must understand that every citizen must necessarily thrive for creation of an orderly state, based on moral foundations. Only such a citizen is a state-creative element, only such a citizen will understand what public work is.

The Galician teachers urged the Ukrainian people to awaken the national activity, to care for their children, to crystallize the purpose and ideal of education, to substantiate practical methods and means for their implementation. The ideal

\footnotetext{
Dilo (1930). March 28.
}

8 Yushchyshyn, I. (1929). Natsionalne vykhovannya [National education]. Shlyakh navchannya i vykhovannya - [The Path of Education and Upbringing], 10. Lviv, p. 1.

9 Yaremkevych, A. (1932). Ohliad pedahohichnoho y osvitnoho rukhu [Review of the pedagogical and educational process]. Shlyakh navchannya $i$ vykhovannya - [The Path of Education and Upbringing], 2. Lviv, p. 115. 
of the national education should be the "work competition", that is, a welleducated citizen who, in the normal and peaceful times, would be capable of everyday productive creative work, which increases the power and the culture of the nation, and in times of misery and danger is capable of sacrifice and dedication for the common good. ${ }^{10}$

The purpose of the Ukrainian national education, according to Volodymyr Kuzmovych (1886-1943), "should be not only the education of a nationally aware Ukrainian who knows his language, literature and history, not only a Ukrainian with perfect mind, heart, will and body, but also a Ukrainian who would be specifically oriented to all the problems of the modern life, that is, nationally oriented." 11 This means that a young person must learn to understand the historical, social, and even cultural phenomena as manifestations or consequences of the reckless and intense struggle of individuals and peoples, to find themselves in modern life. The national orientation was understood as the formation of a sense of solidarity of an individual with the good and interests of the nation, subordination of one's "I" to the interests of the community. And hence the most important task of education is the formation of strong characters, oriented not at oneself, but at the nation, ready for self-sacrifice, with a sense of responsibility. ${ }^{12}$ Youth must be prepared to fight for all that is most holy to the nation, to be committed, active and to grow up to be worthy citizens of their nation.

The scholars raised the problem of the priority of the common over the personal. The education had to reconcile the personal interests with the common ones, but so that one's own freedom was not a restriction on the freedom of the collective. A positive solution to this problem can be found only when knowledge and education together provide what is the content of educational work. Considering the historical and socio-economic conditions in which Galicia's Ukrainians found themselves, the schooling policy became particularly important. "In normal relations, the school issue requires a great deal of attention to itself, noted Mykhaylo Halushchynskyi (1878-1939). When relations are unusual, when the government school and its related education are losing more and more their national character, and when trying to save the character through private schooling meets with obstacles and suppressions, then the attention to the school issue must be appropriately deep and expedient." 13

10 Yushchyshyn, I. (1929). Natsionalne vykhovannya [National education]. Shlyakh navchannya i vykhovannya - [The Path of Education and Upbringing], 2. Lviv, p. 6-7.

11 Kuzmovych, V. (1929). Moyi pomichennya shchodo vykhovannya, navchannya y orhanizatsiyi himnaziy Ridnoyi Shkoly [My remarks on the education, training and organization of Ukrainian grammar schools]. Ukrainian School - [Ukrayinska shkola], 1-4. Lviv, p. 12.

12 Ibidem, p. 13.

${ }^{13}$ Halushchynskyi, M. (1922). Knyzhka i ukrayinske hromadianstvo [The book and Ukrainian citizenship]. Literaturno-Naukovyy Visnyk - [Literary and Scientific Bulletin]. Annual XXI. Is. LXXYIII. B. VII. Lviv, p. 79. 
It is difficult to resolve the I vs Society dilemma because an individual is a member of many community groups. The smallest social cell is the family whose task is to civically educate the individual, to instil the love for the motherland, and to evoke the national awareness. The school, properly organized and built for the needs of the people, should continue this work, and the church should sanctify the sacrifice in the name of the common good. Mykhaylo Halushchynskyi concludes that the moral strength to stand up for oneself and for one's community, and in particular to convince other communities of the impossibility of a solution based on victory, is provided by education, consisting of knowledge and upbringing. ${ }^{14}$ The knowledge gives orientation to the complexity of the issue, and upbringing gives the moral strength. And when there is a struggle between communities that occupy in opposite positions, but call everyone to themselves in the name of a high idea, then the future of the people will depend on the education of the community and everyone.

Ivan Velyhorskyi (1889-1955) believed that a new type person is one who is educated on the national traditions, independent, prepared for life, who "would be able to draw from the past, look reasonably at the present with faith in the future and with a desire for common work in order to build a better future." 15 Determining the ultimate goal of raising a Ukrainian child, Lev Yasinchuk (1882-1953) stated that it "should be a people with one thought and one competition, with one character". Considering the purpose of education, "we should see only a Ukrainian; we must see in the child the essence that arose from our blood that grew on our chunk"16, that is, to educate a patriot of Ukraine capable of building an independent state. "In the times of building our state and defending it against our enemies, it would be desirable to embrace as patriotic as possible to give all the strength to our native land. We see how in the XIX century. The patriotic enthusiasm of the Germans gave them the competitions of small groups of Western Slavs - Czechs, Serbs, Bulgarians - to enable these peoples to gain their national independence."17

The highest imperative in education is Ukrainian statehood. It was about educating on the national soil a conscious citizen who knows not only his language, literature and history, but also is aware of his belonging to the nation and is able to build his own state, actively participates in state-making processes, a person with a clear conscience, honest, decent, the main features of which would be courage, love for the country, devotion and more. It is a person of a new type,

14 Dilo (1924). February 6.

15 Velyhorskyi, I. (1934). Ukrayinoznavstvo [Ukrainian Studies]. Ukrayinska shkola [Ukrainian School], 1. Lviv, p. 14.

16 Yasinchuk, L. (1935). Nash vykhid [Our way out]. Ridna shkola - [Native school], 15-16, Lviv, p. 227.

17 Tsentralnyi derzhavnyi arkhiv vyshchykh orhaniv vlady ta upravlinnia [Central State Archives of Higher Administration], F. 3889, op. 1, spr. 43. 
educated on national traditions, independent, prepared for life, who "would be able to draw from the past, look reasonably for the present with faith in the future and with the desire for active cooperation in building a better Tomorrow." 18

Ukrainian educators (Petro Bilaniuk (1894-1977), Volodymyr Kuzmovych (1886-1943), Vasyl Pachovsky (1878-1942), etc.) put national values at the forefront: the national idea and the ideas of Ukrainian national and spiritual unity, national unity, national self-respect. Mykhaylo Halushchynsky, Stepan Siropolko, Ivan Yushchyshyn and others. They emphasized that the basis of national education should be the Ukrainian national idea, the idea of building an independent Ukrainian state, which should become for the younger generations a "new religion". The idea of state-national education in Ukrainian schooling had to be solved through the prism of those tasks and aspirations that would meet the centuries-old hopes of the Ukrainian people to restore and build their own, independent and cathedral state.

The national idea pervaded speeches at the First Ukrainian Pedagogical Congress (Lviv, 1935). At the first meeting Volodymyr Kuzmovych proposed to include the following topics in the group of educational essays: "Ukrainian educational idea (national and public education, connection of national and public education with the aspiration of the nation)", "Subjects of study (Ukrainian language, history) and Ukrainian Educational Idea", "Faces of Ukrainian Youth (Youth and the Environment, Youth and School, Youth Organizations, Educational Factors, Intelligentsia and Character of Youth)", "New Educational and Pedagogical Experiences in the Ukrainian School", "Youth and Books, Youth Publishers". In Congress, it was emphasized that national education creates the conditions for the fullest account of natural inclinations, formation of national character, way of thinking and feeling of children. It is about education of national consciousness, self-consciousness, formation of national type of personality, which will ensure spiritual unity of generations, continuity of national culture and immortality of the nation ${ }^{19}$. According to Ivan Yushchyshyn, the Congress "crystallized the purpose and ideal of youth education and concentrated practical methods and means for its realization" 20 .

The Congress discussed the issues of education of national consciousness, selfconsciousness, formation of national type of personality that will ensure spiritual unity of generations, continuity of national culture. The national consciousness of Ukrainians has developed on the basis of ethnographic differences, peculiarities of

\footnotetext{
18 Velyhorskyi, I. (1934). Ukrayinoznavstvo [Ukrainian Studies]. Ukrayinska shkola [Ukrainian School], 1, Lviv, p. 14.

19 Pershyi Ukrayinskyi Pedahohichnyi Konhres. 1935 [First Ukrainian Pedagogical Congress. 1935]. (1938). Lviv.

20 Yushchyshyn, I. (1938). Dorohovkazy nashoho vykhovannya [Milestones of our education]. Shlyakh navchannya i vykhovannya - [The Path of Education and Upbringing], 3, Lviv, p. 170.
} 
the psyche, cultural aspirations, layers that link Ukraine to Europe, and the historically predetermined way of national life imbued with the spirit of democracy. The national consciousness is formed by all means of native language, history, geography, folk art, folk customs and traditions, etc. Educators considered a reliable foundation on which the national consciousness of Ukrainians was successfully formed, a historical memory that preserves every page of life, the struggle of the native people for social, political and national rights at all stages of its development. ${ }^{21}$ According to the beliefs of Yakym Yarema (1884-1963), Stefan Baley (1885-1952), Yaroslav Kuzmiv (1897-1945), national consciousness is formed when it has a solid ground for this - a system of ideas, ideals, and spiritual values that have been developed throughout ages. In addition, national consciousness determines the content of the child's activity. "Conscious, Petro Bilaniuk wrote, we call a person who, like a tree, has deeply rooted in its national soil and from there derives its spiritual nourishment, for which the life of one's own people is the source of the strongest feelings and experiences." 22 It should be noted that without national consciousness, without involving a child in national traditions, it is inappropriate to speak of any national education beyond the influence of the mother tongue. This issue was addressed by the speeches of Volodymyr Kuzmovych, Vasyl Pachovsky, Volodymyr Sichynsky (1894-1962), Stanislav Ludkevich (1879-1979) and others. They believed that Ukrainian pedagogy should bring national values to the fore. The task of teachers is to create a sense of pride in their culture for students, which is a testament to the equality of Ukrainians with national peoples. The main values that the school should produce are national self-respect, personal dignity and spiritual pride in being a Ukrainian nation.

In this context, the views of Yaroslav Kuzmiv on the role of education in the development of national consciousness of Ukrainians are interesting. In his view, education in order to reach his or her goal must take into account the following steps that lead the child to: "1) give the child the opportunity to understand and enjoy the cultural heritage made by previous generations, 2) to develop the child so that on the basis of those assets, she created something new, became a creative participant of national culture." ${ }^{23}$ So, the purpose of national education Yaroslav Kuzmiv saw in the awakening and constant strengthening of national consciousness, the unity of all segments of the people around his common national ideals, comprehensive knowledge of the conditions of life of the people inherent in his features.

$21 \quad$ Ibid., p. 89-114.

22 Bilaniuk, P. (1937). Znachinnya vykhovannya [The importance of education]. Ridna shkola - [Native school], 20. Lviv, pp. 282-285.

23 Pershyi Ukrayinskyi Pedahohichnyi Konhres. 1935 [First Ukrainian Pedagogical Congress. 1935]. (1938). Lviv. 
The national consciousness, according to Volodymyr Tselevych (1891-1943), is that holds together the members of the nation, which creates from millions of units a spontaneous community in the days of joy and sorrow. The national consciousness cannot be torn out of the soul of units by any violence. It is possible to kill a person, but there is no way to break it from the heart of national consciousness. As long as the national consciousness of joint competitions glows in the hearts of millions, so long a nation lives and has no power to destroy it. ${ }^{24}$ National consciousness as an instinct, Ivan Yushchyshyn noted, has no kinetic force, only a passive one that can resist, but is unable to create one's own life, it simply exists, it matters. Real creative value is something that can be understood as an idea and as an idea embodied in kinetic power to the extent that it can become a pleasure and a source of activity. "In the world of ideas, only ideas so clearly understood generate electricity. The people must become an idea, to become a dynamic force later." 25

The problem of formation of patriotic feelings among students was justified by Julian Dzerovych (1871-1943). The basis of love for one's people is attachment to one's nest, one's homeland. "A child is attached to nature in the immediate world and the people around him. She loves her family place with all its natural riches and beauty, she loves her mother tongue and songs, costumes and customs." 26 Those natural feelings of love for one's family are strengthened, spread and realized in a child already at preschool age through home influence. Patriotism is taught by a child under the guidance of a caregiver at every opportunity, during conversations, in the study of Geography, History, Geology, Natural History, etc. Even while teaching mathematics and foreign languages, a skilled teacher will be able to pick up a task, and it is already very easy to learn in the folk spirit singing, motions, drawings and handicrafts. ${ }^{27}$ Before that, the pupil must understand that it is not enough for his people to desire development, to speak well about it to strangers, and not to allow strangers to ridicule our history or our folk customs. Patriotism requires service to the Motherland at school, to study well, to be proficient and accustomed to work, to enrich their knowledge and become accustomed to work, to develop in themselves a strong character, to control passions and bad inclinations, and to refine their feelings in that thought, to serve their people. All this is already active patriotism for the child. ${ }^{28}$ Who in the love of adulthood will put the interests of the people above personal, class, party interests,

\footnotetext{
24 Tselevych, V. (1934). Narid. Natsiya. Derzhava [People. Nation. State.]. "Nash chas" "Our time". Vinnytsya, p. 37.

27 Ibid., p. 217.

28 Ibid., p. 217.
} 
and not be limited to complaining, singing patriotic songs and participating in patriotic celebrations, but will not spare time, money and labor to truly cause for the good of the nation as in time peace and during the war. ${ }^{29}$

Ostap Makarushka (1867-1931) emphasized the importance of universal and national values in education. The spiritual world of man is a multifaceted link of the general characteristic of man. It is important to shape and fill it from childhood. The factor of belonging to the people goes through the red thread through human life. ${ }^{30}$ The patriotic feelings embedded in the youth subsequently shape the character of the young person, their way of thinking, influence their behaviour and actions. The teacher not only by his own example, but also by stories, stories, a combination of appropriate proofreading can foster feelings of compassion and love for his neighbour. For this purpose, the teacher should not confine himself to retreats in school books, but offer children stories contained in the books of the school library, and at the same time tell of cases of love for one's neighbour from everyday life, witnessed by children. ${ }^{31}$

The new generation of young people should be educated so that it stands on the guard of state and national interests, it is necessary to teach it to love living life, native language, culture, and way of life, to find beauty in the environment. ${ }^{32}$ According to Ivan Yushchyshyn, new units and a new society must be brought up in a new school and out of school. The new school is determined by the fact that it not only teaches, but also tries to educate its students. She considers education to be her first task, and refers to formal education as the basis of human intellectual development as one of the most important means of education..$^{33}$ To educate active, useful and conscious members is a school in which all educational work must concentrate on the one truth: "without individual human expedient units there is no society, one cannot develop and live outside society and without society." 34

The historical and pedagogical analysis of the theory and practice of national education of Ukrainian youth in the interwar period suggests that the main values are patriotism, national respect, personal dignity and spiritual pride in belonging

29 Ibid., p. 218.

30 Makarushka, O. (1917). Vartist realnykh predmetiv nauky dlya ideyi natsionalnoho obrazovanyya [The importance of real learning disciplines for the idea of the national education]. Nasha shkola - [Our school], 5-6. Lviv, p. 38.

31 Makarushka, O. (1922). Nauka vykhovannya. Pidruchnyk dlya shkil i rodyn [Theory of education. Textbook for schools and families]. Lviv, p. 74.

32 Vavrysevych, M. (1922). Smilyvo do pratsi [Courageous to work]. Uchytelske slovo [Teacher's Word], 11-12. Lviv, p. 3.

${ }^{33}$ Yushchyshyn, I. (1937). Znachennya suchasnoho fizychnoho vykhovannya. [The importance of modern physical training.]. Shlyakh navchannya i vykhovannya - [The Path of Education and Upbringing], 1. Lviv, p. 11.

34 Yushchyshyn, I. (1939). Dva chynnyky suspilnoho vykhovannya v shkoli [Two factors of civic education at school]. Uchytelske slovo - [Teacher's Word], 13. Lviv, p. 107. 
to the Ukrainian nation. The primary task of Ukrainian education was the formation of a patriot, a citizen, a conscious Ukrainian who would take a constructive part in the process of state formation. A patriot is one who loves the People and the Fatherland, who with a passionate heart embraces all her lands and all her countrymen, who hears the son of those lands and the brother of his countrymen, who wants to live not for himself but for the Fatherland, who is ready to die for her, as will be needed. It is not enough just to sympathize with everyone, not only to call yourself a patriot, but to prove a cause, to do so and to act. ${ }^{35}$

The foregoing suggests that, under national education, Ukrainian educators understood the education of nationally conscious Ukrainian youth capable of actively fighting for the independence of Ukraine and of their own creative work to benefit the native people. This theoretical position was realized through a consistent, uncompromising struggle for mother tongue learning; through the saturation of the content of education with Ukrainian material. The analysis of the source base gives an opportunity to distinguish the approaches of Ukrainian educators to the educational ideal, purpose, content and tasks of national education: the first of them envisaged the unification of all segments of the population around the Ukrainian national idea, education of strong characters to focus on working together for the benefit of the future Ukrainian state, overcoming excessive individualism (M. Halushchynsky, V. Kuzmovych, I. Yushchyshyn, L. Yasinchuk, etc.); the second is aimed mainly at awakening and constant strengthening of the national consciousness, uniting all sections of the Ukrainian people around national ideals, using Ukrainian studies as a "backbone of the school" (S. Baley, I. Velyhorskyi, Y. Kuzmiv, V. Pachovsky, Y. Yarema etc.); the third approach focused on a qualitatively new content of education, which closely intertwined national and universal values (P. Bilaniuk, I. Vavrysevych, Y. Dzherovych, O. Makarushka, etc.).

These approaches are still relevant now that Ukrainian education and education are undergoing a national revival process, gradually freeing themselves from the ideology of totalitarianism, being filled with new educational content, which also involves uniting around the educational idea, bringing up a citizen to work together for the benefit of the Ukrainian state, introduction to the schools of science of Ukrainian studies, conversion to religion. For pedagogical theory and practice, it is important that national values are not given to the child from birth, but are formed in the process of personality development, its acquisition of social experience. Ideas, concepts, practical experience of those times and now are an invaluable spiritual treasure and a source of development of the methodology of education for the young Ukrainian state.

35 Halushchynskyi, M. (1920). Narodna osvita i vykhovannia: statti i zamitky [Public education and upbringing: articles and notes]. Lviv, p. 19. 